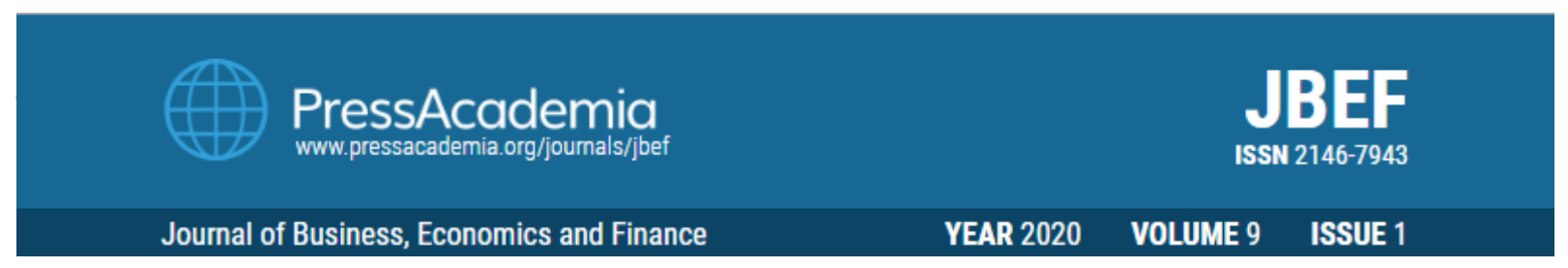

\title{
THE EFFECT OF EXCHANGE RATE VOLATILITY ON ECONOMIC GROWTH IN TURKEY
}

\author{
DOI: 10.17261/Pressacademia.2020.1191 \\ JBEF- V.9-ISS.1-2020(4)-p.42-51
}

\section{Erkan Ozata}

Anadolu University, Department of Economics, Yunus Emre Campus, Faculty of Economics and Administrative Sciences Eskisehir, Turkey. eozata@anadolu.edu.tr, ORCID: 0000-0001-6468-4040

\begin{tabular}{l}
\hline Date Received: January 18, $2020 \quad$ Date Accepted: March 22, 2020 \\
\hline To cite this document \\
Ozata, E., (2020). The effect of exchange rate volatility on economic growth in Turkey. Journal of Business, Economics and Finance (JBEF), \\
V.9(1), p.42-51. \\
Permemant link to this document: $\underline{\text { http://doi.org/10.17261/Pressacademia.2020.1191 }}$ \\
Copyright: Published by PressAcademia and limited licenced re-use rights only.
\end{tabular}

\begin{abstract}
Purpose - Exchange rate volatility, which is defined as continuous fluctuations in exchange rates, has been frequently discussed in the literature recently due to its effects on developing economies. Exchange rate volatility is costly to the domestic economy through its direct and indirect effects on households and firms. Turkey implied different exchange rate regimes between 1980 and 2019 . Also the use of exchange rate as a policy tool for fighting against inflation or current account deficit has increased exchange rate volatility in Turkey. The review of literature on the impact of exchange rate volatility on economic growth provides mixed results. The impact differs from developed to developing countries. The purpose of this study is to examine the impact of exchange rate volatility on economic growth in Turkey between 1998:Q1 and 2019:Q3.

Methodology - This paper uses an Autoregressive Distributed Lag (ARDL) Model to analyze the effect of exchange rate volatility on economic growth in Turkey. Volatility of exchange rate is calculated from the real effective exchange rate by using the GARCH $(1,1)$ model. ARDL model and the bounds testing approach has some advantages over other conventional cointegration approaches. Lagrange Multiplier (LM) test for autocorrelation and Ramsey RESET test for specification error were applied. One last diagnostic test of CUSUM and CUSUMSQ are used to check the stability of the short run and long run coefficient estimates.

Findings- Estimation results of ARDL model show that real effective exchange rate volatility has a negative and highly statistically significant effect on economic growth in Turkey. From the long run coefficients export and investment have a significant positive effect on real GDP, import and exchange rate volatility have significant negative effect on real GDP.

Conclusion- In order to ensure sustainable economic growth, it is necessary to strengthen the fiscal and financial structure and reduce the volatility in exchange rates. Financial deepening and fiscal discipline are very important in this respect. Changing the production structure and investing in education and high technology, increasing the domestic production of intermediate goods are also required for achieving high growth rates.
\end{abstract}

Keywords: Exchange rates, volatility, economic growth, ARDL.

JEL Codes: F43, O42, E44

\section{INTRODUCTION}

Exchange rate volatility, which is defined as continuous fluctuations in exchange rates, has been frequently discussed in the literature recently due to its effects on developing economies. In developed and emerging economies, concerns over exchange rate fluctuations have largely arisen due to their impact on exports, employment growth, foreign trade, inflation, investments and growth. Exchange rate volatility can affect investment and growth through different channels. In theory, the sign of the relationship may vary depending on the assumptions. Many studies support the hypothesis that increased volatility in exchange rates leads to a decline in international trade flows and economic growth. Because the traded goods in most international transactions are using the currency of the exporting or importing country. Therefore, unexpected changes and volatility in exchange rates should adversely affect international trade flows and economic growth due to their impact on profits. Obstfeld and Rogoff's (1995) theoretical work reveals that exchange rate volatility is costly to the domestic economy through its direct and indirect effects on households and firms respectively. The former effect is based on the premise that households remain unhappy about exchange rate movements because of the difficulty in consumption smoothening as well 
as fluctuations in leisure consumption. The indirect effect however assumes that, in an attempt to hedge exchange rate risk, firms set higher prices in the form of risk premium (Alagidede and Muazu, 2016).

On the other hand, there are studies showing that exchange rate volatility has a positive effect on international trade and economic growth. Advocates of this hypothesis say that flexible and more volatile exchange rates enable countries to react to asymmetric shocks, thereby stimulating economic growth. They also assume that volatility also decreases the possibility of speculative attack and prevent financial crises. Given such contradictions, the impact of exchange rate volatility on international trade and economic growth continues to be discussed.

Studies addressing the negative effects of exchange rate uncertainty argue that these effects are realized through the following channels (Demir, 2013): Change the relative cost of production with creative and destructive growth effects, reduce the amount of credits that can be used from the banking system by creating contractionary effects on employment and investment, especially in countries with low levels of financial development decrease productivity growth and aggregate growth, reduce employment and growth by increasing inflation uncertainty, affect growth negatively by increasing interest rates, damage the balance sheets and net worth of the firms and prevent international trade by increasing the transaction risk. In the light of these transmission channels, the effect of exchange rate volatility on growth will depend on firm and country characteristics. For example countries and firms with low risk and high credibility can access to domestic and international capital markets easily and they will not be affected from exchange rate volatility much.

In general, it can be said that exchange rate volatility has a greater impact in developing countries due to defects in fiscal and financial structure. In these countries, low levels of financial market deepening and the lack of financial protection instruments make them vulnerable to the negative effects of exchange rate volatilities. The use of double currencies in contracts and transactions or the indexation of price increases to dollar, which is referred to as dollarization, increases the effects of exchange rate volatility even further.

Flexible exchange rates have been recognized as an important tool for dealing with asymmetrical shocks. The reason for this is that adjustments in the fixed exchange rate regimes are slow and costly due to price and wage rigidities, so that exchange rate adjustments are achieved through relative price and productivity changes. The result is lower growth performance. In contrast, McKinnon (1963) emphasized the benefits of fixed exchange rate regimes for small and open economies against nominal shocks. Since traded goods in small and open economies have a high share in domestic consumption, exchange rate stability also ensures domestic price stability. The welfare effect of fixed exchange rates stems from macroeconomic stability, which provides a favorable environment for investment, consumption and growth. In this respect, monetary and exchange rate policies are seen as the source of uncertainty and volatility in small open economies. We can say that growth will accelerate when exchange rate fluctuations are smoothed.

Turkey implied different exchange rate regimes between 1980 and 2019. The period between 1980 and 1988 is a period in which the real exchange rate is continuously reduced in order to increase the competitiveness of Turkish goods in the international markets and thus to increase exports and reduce imports. During this period, the real exchange rate, was reduced continuously with the devaluation of TL higher than the inflation difference. The production structure of Turkey is dependent on imports of raw materials and intermediate goods. So exports are promoted to decrease the current account deficits. But the most important drawback of using exchange rate to promote exports was to make it harder to combat against inflation. The increase in domestic prices of imported raw materials and intermediate goods with the high depreciation of TL has led to an increase in domestic producer and consumer prices as it has increased production costs. In the late 1980s, the Central Bank began to use the exchange rate as a tool for fighting against inflation due to the risk of rising inflation out of control. So in this period devaluation of $\mathrm{TL}$ is kept low and real exchange rate increases.

The real exchange rate increased continuously during the fixed / controlled exchange rate regime between 1994 and 2001. Turkey moved to a floating exchange rate regime in March 2001. In the 2001-2018 period, the real exchange rate followed a rising trend until 2008, which was gradually replaced by a downward trend following the 2008 crisis. Turkey has faced high levels of economic instability including significant exchange rate volatility and two important banking crises in 1994 and 2001. After the big devaluation of Turkish Lira in 1994 crises real exchange rate has decreased to 58 which is its historical bottom. So the use of exchange rate as a policy tool for fighting against inflation or current account deficit has increased exchange rate volatility in Turkey. Under the floating exchange rate regime imbalances in the foreign capital inflows with the changes in the global economic condition also affects the exchange rate volatility in Turkey.

The rest of the study is organized as follows. Section 2 discusses the empirical literature on the causes of exchange rate volatility and its effects on economic growth. Section 3 outlines the empirical model and the method while section 4 presents the empirical results. Section 5 is conclusion which summarizes the main findings and policy implications. 


\section{LITERATURE REVIEW}

A review of literature on the impact of exchange rate volatility on economic growth provides mixed results. The impact differs from developed to developing countries. Several studies have found significant adverse effects on growth. Other studies have found that exchange rate volatility have positive effects on growth.

Schnabl, (2008) analysis the exchange rate volatility and Growth relationship in Emerging Europe and East Asia. To identify the effect of exchange rate volatility on growth, they specify an unbalanced cross-country panel model for 17 Emerging European countries and 9 East Asian countries. The estimation results for Emerging Europe with respect to exchange rate volatility against the euro provide evidence in favor of a negative correlation between exchange rate volatility and growth. The specification for the whole sample with all control variables suggests that exchange rate volatility against the euro has a clearly negative impact on growth.

Demir (2013) employs a firm level dataset to analyze the effects of exchange rate volatility on the growth performances of domestic versus foreign, and publicly traded versus non-traded private manufacturing firms in, Turkey. The empirical results using dynamic panel data estimation techniques suggest that exchange rate volatility has a significant growth reducing effect on manufacturing firms. However, having access to foreign and domestic equity markets is found to reduce these negative effects at significant levels. Yıldız, Ide, and Malik (2016) use Engle-Granger cointegration approach to explore Turkey's economic growth and exchange rate volatility relationship, by using quarterly data for the period 1998:1-2014:4. The results provide evidence for the existence of both short and long term relationship between economic growth and real effective exchange rate. On the other hand there are some studies who find a positive relationship between exchange rate volatility and growth. Kasman and Kasman (2005) investigates the impact of real exchange rate volatility on Turkey's exports to its most important trading partners using quarterly data for the period 1982 to 2001 . Their results indicate that exchange rate volatility has a significant positive effect on export volume in the long run. This result may indicate that firms operating in a small economy, like Turkey, have little option for dealing with increased exchange rate risk.

Adeniyi and Olasunkanmi (2019) use ARDL model to examine the impact of exchange rate volatility on economic growth in Nigeria. The results revealed that there is existence of co integration among the variables. The findings also exhibited significant impact of export on Gross Domestic Product while import is insignificant both in the short and the long run. The study established insignificant positive relationship between exchange rate volatility and economic growth in Nigeria. On the other hand Sabina, Manyo, and Ugochukwu (2017) find a negative relationship between exchange rate volatility and economic growth in Nigeria. They employ the Generalized Method of Moments (GMM) in estimating the impact of volatility and economic growth in Nigeria and the result show that volatility and FDI has negative and significant impact on the growth of the Nigerian economy. Government Expenditure and External Reserve has positive and significant impact on the growth of the Nigerian economy for the period under study. The study recommend that government and monetary authorities should design policies that will stabilize the persistence volatility in naira exchange rate. Odili (2015) analyze the impact of real exchange rate volatility and economic growth on exports and imports in Nigeria using a vector error correction model and employ time series data from 1971 to 2012 . The study finds that in both the short-run and long-run, Nigeria's trade flows were chiefly influenced by exchange rate volatility, real exchange rates, real foreign income, real gross domestic product, terms of trade and exchange rate policy switch. The findings further reveal that exchange rate volatility depressed trade flows in the long-run.

Ahiabor and Amoah (2019) uses the Fully Modified Ordinary Least Squares (FMOLS) and an annual times series data spanning from 1980-2015 to examine the effect of real effective exchange rate volatility on economic growth in Ghana. Regression results show that real effective exchange rate volatility has a negative and highly statistically significant effect on economic growth in Ghana. In addition, they estimated models with traditional control variables as well as a novel measure of financial market fragility and still have consistent results. Hussain and Farooq (2009) investigate the relationship between economic growth and exchange rate volatility in Pakistan by using an ARDL model. Cointegration relationship between growth, exchange rate volatility, reserve money and manufacturing are detected in the long run except exports and imports. Conclusion suggests that domestic economic performance is very sensitive to the exchange rate volatility in the long-run.

Umaru and Davies (2018) examines the effects of exchange rate volatility on economic growth of West African English speaking countries. The results obtained showed that the independent variable (real exchange rate) is statistically significant and negatively related to the dependent variable (GDP) in West African English speaking countries excluding time-invariant variables. Musyoki, Pokhariyal and Pundo (2012) use Generalized Method Moments (GMM) to assess the impact of the real exchange rate volatility on economic growth for the period January 1993 to December 2009 in Kenya. The study found that RER was very volatile for the entire study period. Kenya's RER generally exhibited an appreciation and volatility trend, implying that the country's international competitiveness deteriorated over the study period. The RER Volatility reflected a negative impact on economic growth of Kenya. Bleaney and Greenaway (2001) estimated investment and growth equations 
on a reasonably sized panel of annual data from 14 sub-Saharan African countries from 1980 to 1995 . Sub-Saharan Africa was selected as a low-income area that is heavily dependent on exports of primary products. They find that real exchange rate volatility has a significant negative impact on investment, and that volatility in the terms of trade has a negative impact on growth.

\section{DATA AND METHODOLOGY}

Cointegration method is used in the analysis of long term relationships between variables. Engle and Granger (1987), Johansen and Juselius (1990) and Johansen (1991) are the most commonly used tests for testing cointegration. The Autoregressive Distributed Lag (ARDL) model and the bounds testing approach which is developed by Pesaran and Shin (1999) and Pesaran, Shin, and Smith (2001) has some advantages over other conventional cointegration approaches. Unlike the other cointegration methods, there is no limiting assumption that all variables used in the ARDL model should be integrated of the same order. Therefore, I(0) and I(1) variables can be used together. However, as a limiting condition, no variable should be integrated of the second or higher order. With this approach, problems arising from non-stationary series are largely eliminated. In addition, the variables included in the analysis may have different lag lengths which is not possible in the VAR modelling. Another advantage of the ARDL model is that short and long term parameters can be estimated together. By applying linear transformation to the model, it makes possible to obtain an Error Correction Model that combines short-term and long-term relationships without losing long-term information. Another important advantage is that it can be applied to small samples. It gives consistent and reliable results even in samples with limited observations.

$$
\ln G D P=\alpha+\beta_{1} \ln E x p+\beta_{2} \ln \operatorname{Imp}+\beta_{3} \ln \operatorname{In} v+\beta_{4} \ln \text { Volex }+\varepsilon_{t}
$$

Where GDP is the Real Gross Domestic Product, Exp is the exports of goods and services, Imp is the import of goods and services, Inv is the gross fixed capital formation which represents investment, Volex is the volatility of exchange rate which is calculated from the real effective Exchange rate by using the GARCH $(1,1)$ model. If we estimate equation (1) by OLS or any other linear method, we obtain long-run effects of the explanatory variables on the explained variable (GDP). But the error correction modelling approach offers an opportunity to also estimate the short run effects. Moreover Pesaran et al., (2001) bounds testing approach has an advantage of estimating short-run and long-run effects in one step. Because of the mentioned advantages the ARDL model in equation (2) is estimated.

$$
\begin{aligned}
& \Delta \operatorname{LnGDP}_{t}=\alpha_{0}+\sum_{i=1}^{n 1} \alpha_{1 i} \Delta \operatorname{LnGDP}_{t-i}+\sum_{i=0}^{n 2} \alpha_{2 i} \Delta \operatorname{LnExp_{t-i}}+\sum_{i=0}^{n 3} \alpha_{3 i} \Delta \operatorname{LnImp}_{t-i}+\sum_{i=0}^{n 4} \alpha_{4 i} \Delta \operatorname{LnInv}_{t-i}+ \\
& \sum_{i=0}^{n 5} \alpha_{5 i} \Delta \text { Lnvolex }_{t-i}+\lambda_{1} \operatorname{LnGDP}_{t-1}+\lambda_{2} \operatorname{LnExp}_{t-1}+\lambda_{3} \operatorname{LnImp}_{t-1}+\lambda_{4} \operatorname{LnInv}_{t-1}+\lambda_{5} \text { LnVolex }_{t-1}+\varepsilon_{t}
\end{aligned}
$$

The coefficients from $\lambda_{1}$ to $\lambda_{5}$ show the long-run relationship between the variables and the coefficients from $\alpha_{1 i}$ to $\alpha_{5 i}$ show the dynamic short run relationships among the variables. For example the short-run effects of exchange rate volatility on real GDP are inferred by the estimates of $\alpha_{5 i}{ }^{\prime} \mathrm{s} . \Delta$ is the first difference operator, $\alpha_{0}$ is the constant and $\varepsilon_{t}$ is the white noise error term.

The analysis of short- and long-term dynamics with the ARDL bounds test approach requires a process consisting of several steps. In the first step, Model (2) is estimated by OLS method and an F test is used to examine the long-run relationship between variables and test the coefficients of lagged variables together. The null hypothesis $H_{0}: \lambda_{1}=\lambda_{2}=\lambda_{3}=\lambda_{4}=\lambda_{5}=0$ indicates that there is no long-term relationship or cointegration between variables. The alternative hypothesis states that the lagged coefficients are significant and there is a cointegration relationship among them. The sample value of the calculated F statistic is compared with the critical upper and lower limits created by Pesaran et al., (2001). If the sample value of the calculated F statistic is less than the table lower bound, the null hypothesis stating that there is no cointegration is not rejected. However, if the sample value of the calculated F statistic is greater than the upper bound of the table, the null hypothesis is rejected and the existence of a long-run relationship between the variables in the model is determined. The test is inconclusive if the calculated F statistic is between the upper and lower bound.

After determining the cointegration relationship, in the second step, appropriate lag lengths for the variables are determined by using model selection criteria such as Hannan Quinn Criteria, Akaike Information Criteria (AIC), Schwarz Criteria (SBC). In the third step, by using the information from model (2) the error correction model is estimated. 


$$
\begin{aligned}
& \Delta \operatorname{LnGDP}_{t}=\alpha_{0}+\sum_{i=1}^{n 1} \alpha_{1 i} \Delta \operatorname{LnGDP}_{t-i}+\sum_{i=0}^{n 2} \alpha_{2 i} \Delta \operatorname{LnExp}_{t-i}+\sum_{i=0}^{n 3} \alpha_{3 i} \Delta \operatorname{LnImp}_{t-i}+\sum_{i=0}^{n 4} \alpha_{4 i} \Delta \operatorname{LnInv}_{t-i}+ \\
& \sum_{i=0}^{n 5} \alpha_{5 i} \Delta \text { LnVolex }_{t-i}+\varphi \operatorname{ECM}_{t-1}+\varepsilon_{t}
\end{aligned}
$$

The coefficients from $\alpha_{1}$ to $\alpha_{5}$ are the short term dynamic coefficients that stabilize the model. ECM is the error correction term and its coefficient $\varphi$ shows the speed of adjustment of the model to the long - term equilibrium after a short - term shock. This coefficient should be negative and statistically significant.

For testing the stability of the estimated model, CUSUM and CUSUMSQ tests which are developed by (Pesaran, M. H., Shin, 1999) and (Brown, Durbin, and Evans, 1975) are recommended. CUSUM and CUSUMSQ statistics are recursive estimates and they are marked against breakpoints. Visual inspection of recursive estimates provides information about structural breaks or stability of the model. If the CUSUM and CUSUMSQ statistics are within the critical limits drawn at the $5 \%$ significance level, the null hypothesis which states that the model is stable is not rejected.

\section{FINDINGS AND DISCUSSIONS}

The ARDL model by using quarterly data from Turkey between 1998:Q1 and 2019:Q3 is estimated. Data for real GDP, exports, imports and investment are obtained from The Central Bank of the Republic of Turkey. Volatility measure of the effective exchange rate is generated by using a GARCH approach.

When discussing the volatility of time series, econometricians refer to the 'conditional variance of the data, and the timevarying volatility of asset returns is known as conditional heteroscedasticity. The GARCH Model is an extension of the ARCH model developed by Engle (1982) which considers the variance of the current error term to be a function of the variance of the previous error terms. GARCH allows the variance of the variable of concern to change over time. As mentioned by Bahmani-Oskooee and $\mathrm{Xi}$ (2012) it assumes that REER is a random variable which is drawn from a conditional density function $f\left(R E E R \mid R E E R_{t-1}\right)$. The theoretical specification of the GARCH model is as follows:

$R E E R=\alpha_{0}+\alpha_{1} R E E R_{t-1}+\varepsilon_{t}$

$\varepsilon_{t} \mid I_{t-1} \square N\left(0, h_{t}^{2}\right)$

$V\left(R E E R_{t} \mid I_{t-1}\right)=V\left(\varepsilon_{t} \mid I_{t-1}\right)=h_{t}^{2}$

$h_{t}^{2}=\delta+\alpha_{1} \varepsilon_{t-1}^{2}+\alpha_{2} \varepsilon_{t-2}^{2}+\ldots \ldots \ldots \ldots \ldots \ldots \ldots . .+\alpha_{p} \varepsilon_{t-p}^{2}+\beta_{1} h_{t-1}^{2}+\beta_{2} h_{t-2}^{2}+\ldots \ldots \ldots . . \beta_{q} h_{t-q}^{2}$

A GARCH $(p, q)$ model can be written as

$$
h_{t}^{2}=\delta+\sum_{j=1}^{p} \alpha_{j} \varepsilon_{t-j}^{2}+\sum_{j=1}^{q} \beta_{j} h_{t-j}
$$

The order of GARCH is determined by the significance of $\alpha^{\prime} s$ and $\beta^{\prime} s$ in equation (8). In most instances, a GARCH $(1,1)$ model is sufficient.

$h_{t}^{2}=\delta+\alpha_{1} \varepsilon_{t-1}^{2}+\beta_{1} h_{t-1}^{2}$

Since a variable is mostly explained by its own past values, a higher value for $\beta_{1}$ and a lower value for $\alpha_{1}$ is expected. Volatility is said to be persistent if the coefficient of the GARCH term is large. Bollerslev (1986) identified the condition required for the stationarity of the model as:

$\sum_{j=1}^{p} \alpha_{j}+\sum_{j=1}^{q} \beta_{j}<1$ 
As stated by Sabina, Manyo, and Ugochukwu, (2017) stationarity of the GARCH model ensures that the behavior and properties of the estimators do not change over time and that the persistence of the shock is not infinite.

Table 1: GARCH $(1,1)$ Equation

\begin{tabular}{|l|c|c|c|c|}
\hline \multicolumn{1}{|c|}{ Variable } & Coefficient & Std. Error & z-statistic & Prob \\
\hline C & 20,96682 & 6.906575 & 3.035777 & 0.0024 \\
\hline REER(-1) & 0.791750 & 0.063497 & 12.46903 & 0.0000 \\
\hline \multicolumn{4}{|c|}{ Variance Equation } \\
\hline C & 9.597075 & 10.64650 & 3.035777 & 0.3674 \\
\hline RESID(-1)^2 & 0.536468 & 0.217057 & 2.471547 & 0.0135 \\
\hline GARCH(-1) & 0.365714 & 0,093654 & 3,168452 & 0,0015 \\
\hline
\end{tabular}

As shown in Table 1, the results of the GARCH $(1,1)$ model show that there is a permanent shock affecting the volatility of the real effective exchange rate. The coefficients of ARCH and GARCH terms are positive and they are significant at $\% 5$ significance level. Also the sum of ARCH and GARCH terms are smaller than 1 which means that the estimated GARCH model is stationary. The coefficient of the ARCH term is greater than that of GARCH term indicating that volatility in the exchange rate tends to be more extreme.

Figure 1: Conditional Variance from GARCH $(1,1)$ Model

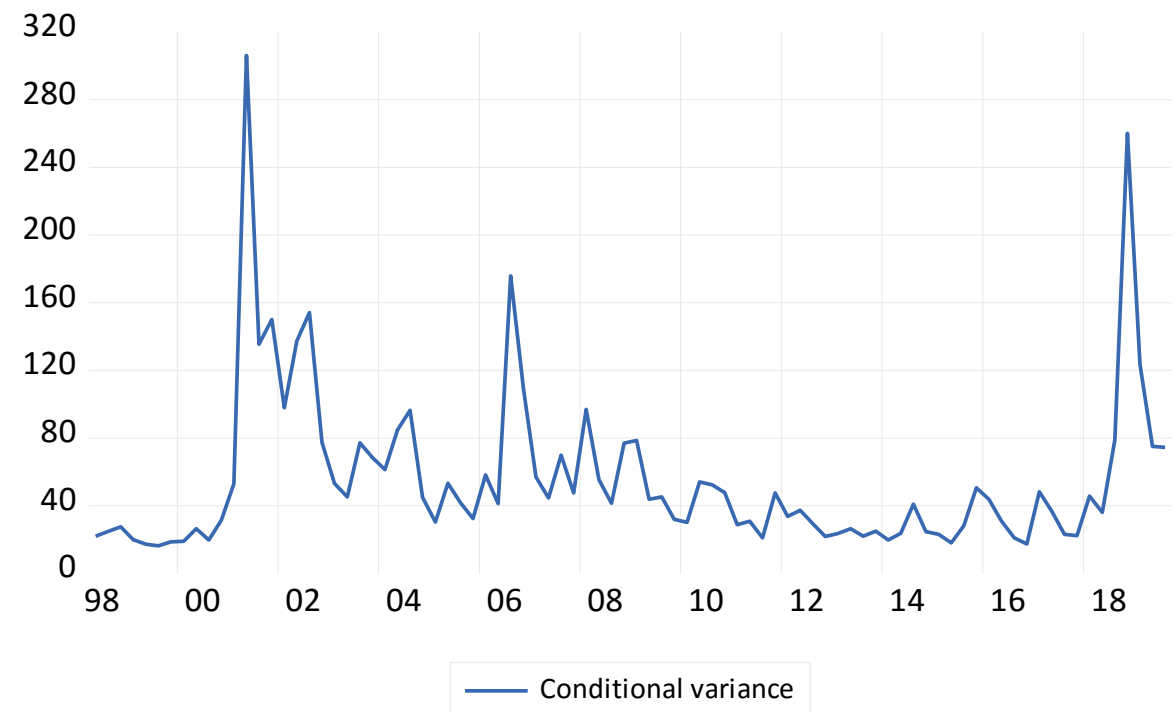

Figure 1 shows that increase in the volatility during the crises years of 2001, 2007 and 2018 can easily be seen from the conditional variance from $\mathrm{GARCH}(1,1)$ model.

Before estimating the ARDL model, the stationarity and degree of integration of the series were investigated using Augmented Dickey Fuller (ADF) and Phillips Perron unit root tests. Our purpose is to make sure that none of the series is I (2). Because the critical F values provided by Pesaran et al. (2001) are only valid when the variables are I (0) and I (1). The results of the unit root tests are presented in Table 2.

Table 2: Unit Root Tests

\begin{tabular}{|l|l|l|l|l|}
\hline & \multicolumn{2}{|c|}{ ADF Test } & \multicolumn{2}{c|}{ PP Test } \\
\hline Variable & Intercept & Trend and Intercept & Intercept & Trend and Intercept \\
\hline $\ln G D P_{t}$ & $-0.406189(8)$ & $-3.421303^{*}(4)$ & $-1.196769[15]$ & $-7.080832^{* * *}[16]$ \\
\hline$\Delta \ln G D P_{t}$ & $-4.684016^{* * *}(5)$ & $-3.329880^{*}(3)$ & $-15.76751^{* * *}[13]$ & $-15.63883^{* * *[13]}$ \\
\hline $\ln \operatorname{expo}_{t}$ & $0.180296(3)$ & $-3.102096(4)$ & $-0.392926[18]$ & $-5.744276^{* * *[7]}$ \\
\hline$\Delta \operatorname{lnexpo}_{t}$ & $-10.16610^{* * *}(2)$ & $-10.13316^{* * *(2)}$ & $-15.01292^{* * *[17]}$ & $-14.75020^{* * *[17]}$ \\
\hline
\end{tabular}




\begin{tabular}{|l|l|l|l|l|}
\hline $\operatorname{lnimp}_{t}$ & $-1.426599(5)$ & $-1.501070(5)$ & $-1.282094[9]$ & $-2.418790[3]$ \\
\hline$\Delta \operatorname{lnimp}_{t}$ & $-4.984593^{* * *}(4)$ & $-5.085571^{* * *}(4)$ & $-11.16772^{* * *[3]}$ & $-11.18377^{* * *[4]}$ \\
\hline $\operatorname{lninv}_{t}$ & $-1.480220(8)$ & $-2.930470(8)$ & $-1.023880[29]$ & $-4.222210^{* * *[8]}$ \\
\hline$\Delta \operatorname{lninv}_{t}$ & $-2.910894^{* *}(7)$ & $-3.131167^{* *}(7)$ & $-15.54330^{* * *[7]}$ & $-15.45709^{* * *[7]}$ \\
\hline lnvolex $_{t}$ & $-3.746864^{* *}(0)$ & $-3.760525^{* *}(0)$ & $-3.671949^{* * *[2]}$ & $-3.686273^{* *[2]}$ \\
\hline
\end{tabular}

1) $* * *, * *, *$ represents significance at the $1 \%, 5 \%$ and $10 \%$ level respectively

2) The numbers in () are the lag orders which are determined by Schwarz Info Criteria

3) The numbers in [ ] are the bandwidth which are determined by Newey West using Bartlett kernel

The results of the Augmented Dickey Fuller and Phillips Perron unit root tests show that log of real GDP, exports, imports and investment are not stationary at their levels but they become stationary when their first differences are calculated which means they are I(1). On the other hand exchange rate volatility is stationary at its level which means it is I(0). After confirming that none of the variables is I(2) short run, long run and error correction coefficients of the ARDL model are estimated.

Table 3: Bounds Test

\begin{tabular}{|l|c|c|}
\hline F-Statistic & \multicolumn{2}{|c|}{$20.760 * *$} \\
\hline Critical Values & & \\
\hline Significance Level & Lower Bound & Upper Bound \\
\hline $10 \%$ & 2.2 & 3.09 \\
\hline $5 \%$ & 2.56 & 3.49 \\
\hline $1 \%$ & 3.29 & 4.37 \\
\hline
\end{tabular}

The results of the bounds test to investigate the cointegration relationship between variables are given in Table 3 . The sample value of the calculated $\mathrm{F}$ statistic above the upper bounds at all the significance levels. So the null hypothesis of no cointegration is rejected and a cointegration relationship between the variables is observed. After determining the cointegration relationship between the variables, the coefficients of ARDL $(4,0,4,0,4)$ model which is selected according to Akaike Information Criteria were estimated and the results are presented in Table 4.

Table 4: Estimation Results and Diagnostic Testing

\begin{tabular}{|c|c|c|c|c|c|}
\hline \multicolumn{6}{|c|}{ Panel A: ARDL $(4,0,4,0,4)$ Model } \\
\hline Lag Order & $\ln G D P$ & lnexpo & $\operatorname{lnimp}_{t}$ & lnvolex & $\operatorname{lnin} v_{t}$ \\
\hline \multirow[t]{2}{*}{0} & & 0.141 & 0.061 & -0.006 & 0.235 \\
\hline & & $(3.642)$ & $(1.686)$ & $(-1.772)$ & $(6.566)$ \\
\hline \multirow[t]{2}{*}{1} & 0.199 & & -0.073 & & -0.039 \\
\hline & $(2.159)$ & & $(-1.728)$ & & $(-0.917)$ \\
\hline \multirow[t]{2}{*}{2} & -0.242 & & 0.026 & & 0.095 \\
\hline & $(-2.765)$ & & $(0.568)$ & & $(2.354)$ \\
\hline \multirow[t]{2}{*}{3} & 0.203 & & -0.041 & & $(-0.060)$ \\
\hline & $(2.302)$ & & $(-0.882)$ & & $(-1.468)$ \\
\hline \multirow[t]{2}{*}{4} & 0.631 & & -0.063 & & -0.120 \\
\hline & (7.366) & & $(-1.313)$ & & $(-3.146)$ \\
\hline \multicolumn{6}{|c|}{ Panel B : Long Run Coefficients } \\
\hline Constant & $\operatorname{lnexpo}_{t}$ & $\operatorname{lnimp} p_{t}$ & $\operatorname{lnin} v_{t}$ & lnvolex & \\
\hline 5.683 & 0.681 & -0.435 & 0.531 & -0.031 & \\
\hline$(4.889)$ & $(5.495)$ & $(-2.529)$ & 3.278 & $(-1.729)$ & \\
\hline$[0.000]$ & {$[0.000]$} & [0.013] & {$[0.001]$} & [0.088] & \\
\hline \multicolumn{6}{|c|}{ Panel C: Diagnostic statistics } \\
\hline & $E C M_{t-1}$ & LM & RESET & & Adj. $R^{2}$ \\
\hline & -0.207 & 1,456 & 1.253 & & 0.997 \\
\hline & $(-11.58)$ & {$[0,374]$} & {$[0.267]$} & & \\
\hline
\end{tabular}

Notes: The numbers in parenthesis are the tratios; the numbers in brackets are the prob values. 
From the long run coefficients export and investment has a significant positive effect on real GDP, import and exchange rate volatility have significant negative effect on real GDP. Coefficient of exchange rate volatility is significant at $10 \%$ while the other coefficients from the long run model are significant at $1 \%$. The coefficient of $E C M_{t-1}$ is negative and statistically significant. This shows that the variables adjust towards equilibrium in the long run. Lagrange Multiplier (LM) test for autocorrelation and Ramsey RESET test for specification error were applied. The prob values from both tests are greater than 0.05 which implies that there is no autocorrelation and no specification error in the model. Also the size of the adjusted $\mathrm{R}^{2}$ shows an excellent goodness of fit.

\section{Figure 2: CUSUM and CUSUM SQUARE Tests}
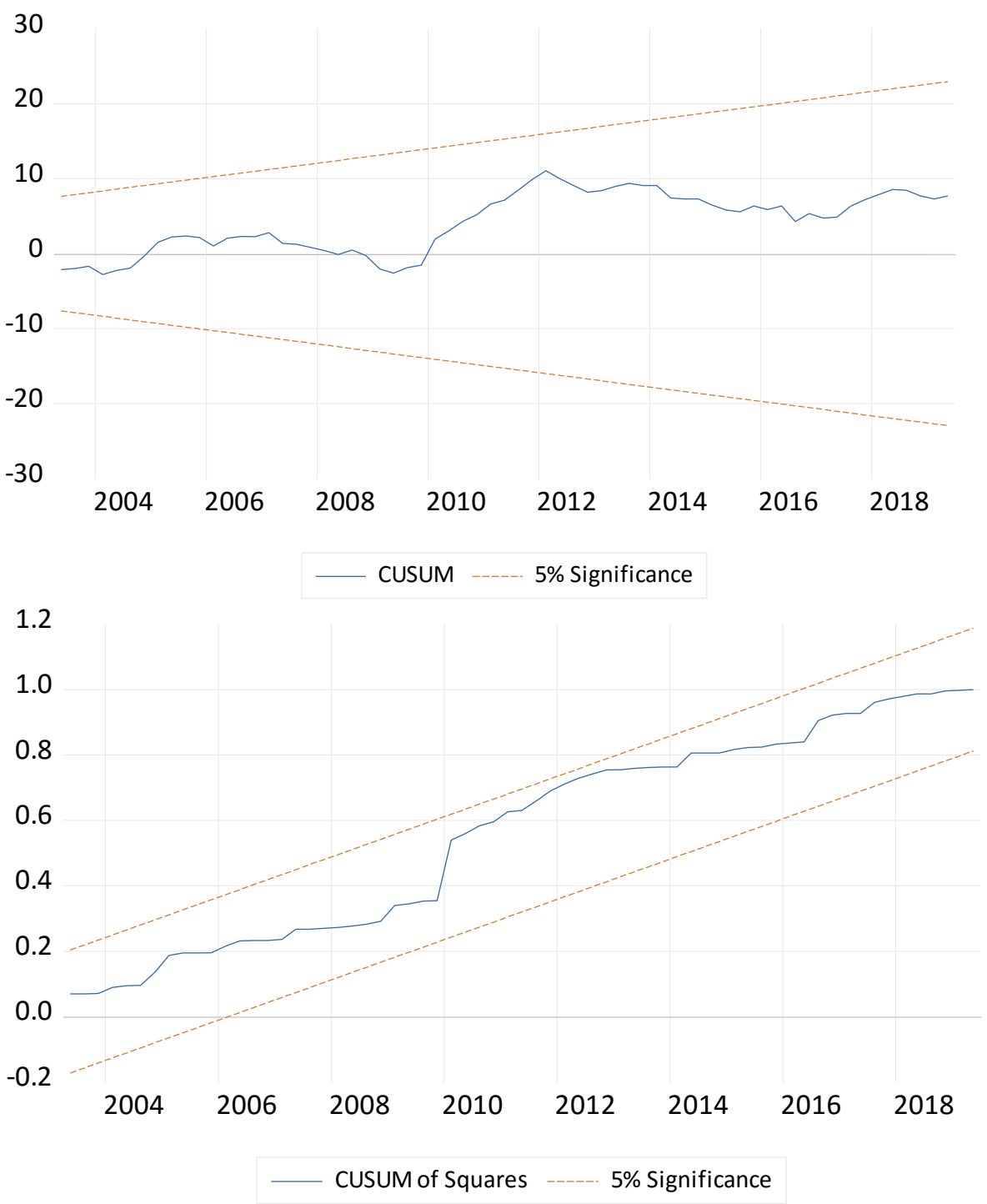

One last diagnostic test is for the stability of the short run and long run coefficient estimates. If the plot of CUSUM and CUSUMSQ stays within the $5 \%$ significance level represented by two straight lines, then the coefficient estimates are stable. As can be seen from Figure 2 both plots of CUSUM and CUSUMSQ remains within the $5 \%$ level of significance represented by two straight lines, implying that the estimated coefficients are stable.

\section{CONCLUSION}

This study examines the impact of exchange rate volatility on economic growth in Turkey between 1998:Q1 and 2019:Q3 by using the Autoregressive Distributed Lag (ARDL) Model. Estimation results show that real effective exchange rate volatility has a negative and highly statistically significant effect on economic growth in Turkey. From the long run coefficients export 
and investment has a significant positive effect on real GDP, import and exchange rate volatility have significant negative effect on real GDP.

Between 1980 and 1988 is a period in which the real exchange rate is continuously reduced in order to increase the competitiveness of Turkish goods in the international markets and thus to increase exports and reduce imports. In the late 1980s, the Central Bank began to use the exchange rate as a tool for fighting against inflation due to the risk of rising inflation out of control. So in this period devaluation of TL is kept low and real exchange rate increases. So the use of exchange rate as a policy tool for fighting against inflation or current account deficit has increased exchange rate volatility in Turkey. Under the floating exchange rate regime imbalances in the foreign capital inflows with the changes in the global economic condition also affects the exchange rate volatility in Turkey. These volatilities in the exchange rate increased the risk and uncertainty in international transactions and negatively affected foreign trade and growth. Due to the production structure which is heavily dependent on the imported inputs, production and growth rate decreased during the high volatility periods.

In order to ensure sustainable economic growth, it is necessary to strengthen the fiscal and financial structure and reduce the volatility in exchange rates. Financial deepening and fiscal discipline is very important in this respect. Changing the production structure and increasing the domestic production of intermediate goods is also required for achieving stable growth rates.

\section{REFERENCES}

Adeniyi, A. P., and Olasunkanmi, A. Olasoji. (2019). Impact of Exchange Rate Volatility on Economic Growth in Nigeria. International Journal Management Studies and Social Science Research, 1(4), 43-48.

Ahiabor, G., and Amoah, A. (2019). Examining the Effect of Real Effective Exchange Rate Volatility on Economic Growth : Evidence From Ghana. Journal of Economics and Economic Education Research, 20(1), 1-14.

Alagidede, Paul and Ibrahim, Muazu. (2016). On the causes and effects of exchange rate volatility on economic growth: Evidence from Ghana. 10.13140/RG.2.1.3300.0722.

Bahmani-Oskooee, M., and Xi, D. (2012). Exchange rate volatility and domestic consumption: Evidence from Japan. Economic Systems, 36(2), 326-335. https://doi.org/10.1016/j.ecosys.2011.10.004

Bleaney, M., and Greenaway, D. (2001). The impact of terms of trade and real exchange rate volatility on investment and growth in subSaharan Africa. Journal of Development Economics, 65(2), 491-500. https://doi.org/10.1016/S0304-3878(01)00147-X

Bollerslev, T. (1986). Generalised Autoregressive Conditional Heteroscedasticity. Journal of Econometrics.

Brown, R., Durbin, J., and Evans, J. (1975). Techniques for testing the constancy of regression relationships over time. Journal of the Royal Statistical Society, 37(2), 149-192. https://doi.org/10.2307/2984889

Demir, F. (2013). Growth under exchange rate volatility: Does access to foreign or domestic equity markets matter? Journal of Development Economics, 100(1), 74-88. https://doi.org/10.1016/j.jdeveco.2012.08.001

Engle, R. F. (1982). Autoregressive Conditional Heteroscedasticity with Estimates of the Variance of United Kingdom Inflation. Econometrica. https://doi.org/10.2307/1912773

Engle, R. F., and Granger, C. W. J. (1987). Co-Integration and Error Correction: Representation, Estimation, and Testing. Econometrica, 55(2), 251. https://doi.org/10.2307/1913236

Eteng F.O. and ljim-Agbor U. (2016). International Journal of Humanities and Social Science Research, 43-48.

Hussain, Z. J., and Farooq, M. (2009). Economic growth and exchange rate volatilityin the case of Pakistan. Pakistan Journal of Life and Social Sciences, $7(2), 112-118$.

Johansen, Soren. (1991). Estimation and Hypothesis Testing of Cointegration Vectors in Gaussian Vector Autoregressive Models. Econometrica, 59(6), 1551. https://doi.org/10.2307/2938278

Johansen, Søren, and Juselius, K. (1990). Maximum Likelihood Estimation and Inference on Cointegration - With Applications to the Demand for Money. Oxford Bulletin of Economics and Statistics, 52(2), 169-210. https://doi.org/10.1111/j.1468-0084.1990.mp52002003.x

Kasman, A., and Kasman, S. (2005). Exchange Rate Uncertainty in Turkey and its Impact on Export Volume. METU Studies in Development, 32(1), 41-53.

McKinnon, R. (1963). Optimum Currency Areas. The American Economic Review, 53(4), 717-725.

Musyoki, D., Pokhariyal, G. P., and Pundo, M. (2012). The Impact of real exchange rate misalignment on economic Growth: Kenyan evidence. Research Journal of Finance and Accounting, 7(1), 59-75. 
Obstfeld, M., and Rogoff, K. (1995). Exchange rate dynamics redux. Journal of Political Economy. https://doi.org/10.1086/261997

Odili, O. (2015). Real Exchange Rate Volatility, Economic Growth and International Trade in an Emerging Market Economy: Evidence from Nigeria. International Journal of Academic Research in Business and Social Sciences, 5(7), 179-201. https://doi.org/10.6007/ijarbss/v5i7/1730

Pesaran, M. H., Shin, Y. (1999). An autoregressive distributed lag modelling approach to cointegration analysis. In Econometrics and Economic Theory in the 20th Century: The Ragnar Frisch Centennial Symposium. (pp. 1-31). https://doi.org/10.1017/CCOL521633230

Pesaran, M. H., Shin, Y., and Smith, R. J. (2001). Bounds testing approaches to the analysis of level relationships. Journal of Applied Econometrics, 16(3), 289-326. https://doi.org/10.1002/jae.616

Sabina, N. E., Manyo, T. S., and Ugochukwu, U. S. (2017). "Exchange Rate Volatility and Economic Growth in Nigeria." International Journal of Economics, Commerce and Management, 5(7), 583-595.

Schnabl, G. (2008). Exchange rate volatility and growth in small open economies at the EMU periphery. Economic Systems, 32(1), 70-91. https://doi.org/10.1016/j.ecosys.2007.06.006

Umaru, H., A, A. N., and Davies, N. O. (2018). The Effects of Exchange Rate Volatility on Economic Growth of West African English-Speaking Countries. International Journal of Academic Research in Accounting, Finance and Management Sciences, 8(4), $131-143$. https://doi.org/10.6007/IJARAFMS/v8-i4/5470

Yıldız, H., Ide, G., and Malik, S. T. (2016). The Relationship Between Exchange Rate Volatility and Economic Growth : an Example of Turkey. International Journal of Arts and Commerce, 5(3), 47-61. 